\title{
ATITUDINI ALE TINERILOR DIN MUN. CHIȘINĂU FAṬĂ DE TRAIUL ÎN UNIUNE CONSENSUÁLĂ
}

\author{
Liliana CUŞNIR ${ }^{\odot}$, cercetător științific, \\ Centrul de Cercetări Demografice al INCE, Republica Moldova \\ DOI: $\underline{\text { https://doi.org/10.36004/nier.cdr.2019.14-21 }}$
}

JEL Classification: J10, J12, J13.

\begin{abstract}
Actualitatea articolului constă în analiza tendințelor recente de conviețuire $\hat{\imath}$ cuplu a tinerilor din Republica Moldova, inclusiv în comparație cu țările din UE, consecințele acestora și provocările viitoare în promovarea valorilor familiale. Scopul a fost în descrierea atitudinii tinerilor din mun. Chișinău față de traiul în uniuni consensuale în baza studiului sociologic "Atitudinile tinerilor față de căsătorie". Se prezintă analiza secundară a datelor studiului sociologic inclusiv și analiza datelor statistice oficiale în baza ultimului Recensământ al Populației și Localităților din 2014. Rezultatele relevă că deși căsătoria este preferată de către tineri și se recunoaște că astfel sunt protejați legal, totuși tinerii au o atitudine pozitivă față de traiul în uniune consensuală, motivând prin faptul că aceasta este o formă ce precedă căsătoria.

Cuvinte-cheie: tineri, uniune consensuală, familie, căsătorie, Republica Moldova, țări europene.

The actuality of this article consists in analysis of recent cohabitation trends of youth in the Republic of Moldova and compared to EU countries, their consequences and future challenges in promoting family values. The purpose was to describe the attitude of young people from Chisinau towards living in consensual unions based on sociological survey "Attitudes of young people towards marriage". The secondary analysis of survey data and analysis of official statistics based on the last Census of Population and Localities (2014) was done. Results show that even if young people choose marriage and admit that in this way they are legally protected, youth still have a positive attitude towards living in consensual union, motivating by the fact that this is a form that precedes marriage.
\end{abstract}

Key words: young people, consensual union, family, marriage, Republic of Moldova, European countries.

Fenomenul uniunii consensuale a început să câștige tot mai mult teren în comparație cu căsătoria, astfel încât Curtea Europeană a Drepturilor Omului (CEDO), în anul 2016, a sugerat necesitatea înregistrării uniunilor consensuale ca tip de aranjament marital neconvențional în țările din UE. Majoritatea statelor europene au legiferat traiul în parteneriat din motive diverse, însă la bază a servit Convenția pentru apărarea Drepturilor Omului și a Libertăţilor Fundamentale.

În prezent există doua modele legislative în țările vest-europene. Unul, întâlnit în Belgia și Franța, numit „,coabitarea legala” și respectiv „,pactul civil de solidaritate” (pacs) desemnat prin expresia „,contract înregistrat”, și cel de-al doilea, întâlnit în Țările Scandinave, în Olanda și Germania, desemnat prin expresia ,parteneriat inregistrat”. Proiectele legislative (scrise în engleză) utilizează noțiunea „parteneriat civil” (civil partnership), care presupune o instituţie ce oferă drepturi și stabilește obligații pentru cupluri, indiferent de modelul de conviețuire, cupluri formate din persoane de sex diferit sau despre cupluri formate din persoane de același sex, care nu doresc sau nu pot să se căsătorească [8]. De exemplu, în Danemarca, Suedia, Finlanda și Germania înregistrarea unui astfel de parteneriat nu este posibilă decât pentru parteneri de acelaşi sex. În Olanda, Belgia și Franța, noile reglementări permit legalizarea indiferent de sexul celor

\footnotetext{
๑ Liliana Cuşnir, cusnir.liliana@mail.ru
} 
doi parteneri prin încheierea unui contract (Tabelul 1.). Datorită acestui fapt, este posibilă stabilirea unei distincții: pe de o parte, sistemele legislative în care partenerii stabilesc un contract de coabitare care poate fi înregistrat apoi de autorităţile guvernamentale și, pe de altă parte, sistemele juridice în care partenerii pot să stabilească un „parteneriat înregistrat”. Cea mai importantă diferență între ,contractul înregistrat” și ,parteneriatul înregistrat” din punct de vedere legal este că înregistrarea unui contract de coabitare nu constituie un obstacol în calea unei căsătorii ulterioare cu o altă persoană și nu are nici un efect asupra stării civile [1].

Tabelul 1. Reglementările actuale privind contractul înregistrat, parteneriatul înregistrat și uniunile consensuale din țările europene

\begin{tabular}{|c|c|c|c|c|}
\hline State & Contract înregistrat & $\begin{array}{c}\text { Parteneriat } \\
\text { innregistrat }\end{array}$ & Uniuni consensuale & Niciunul \\
\hline Belgia & $\mathrm{X}$ & & & \\
\hline Danemarca & & $\mathrm{X}$ & & \\
\hline Germania & & $\mathrm{X}$ & & $\mathrm{X}$ \\
\hline Grecia & & & & $\mathrm{X}$ \\
\hline Spania & & $\mathrm{X}$ & & \\
\hline Finlanda & $\mathrm{X}$ & $\mathrm{X}$ & & \\
\hline Franța & $\mathrm{X}$ & $\mathrm{X}$ & $\mathrm{X}$ \\
\hline Irlanda & & $\mathrm{X}$ & & \\
\hline Italia & & & $\mathrm{X}$ & $\mathrm{X}$ \\
\hline Luxemburg & & $\mathrm{X}$ & \\
\hline Olanda & & $\mathrm{X}$ & & \\
\hline Austria & & & & $\mathrm{X}$ \\
\hline Portugalia & & $\mathrm{X}$ & $\mathrm{X}$ & \\
\hline Suedia & & & & $\mathrm{X}$ \\
\hline Anglia & & & & \\
\hline Estonia & & & & $\mathrm{X}$ \\
\hline Letonia & & & & \\
\hline Malta & & & & \\
\hline Cehia & & & & \\
\hline Slovacia & & & & \\
\hline Ungaria & & & & \\
\hline Polonia & & & & \\
\hline
\end{tabular}

Sursa: ANTIGONA I. Istoria căsătoriei și a divorțului [1]

Un interes deosebit în cercetarea comportamentului matrimonial privind schimbările recente care au avut loc în Europa Centrală și de Est, precum și interpretarea lor de oamenii de știință din străinătate au întărit cadrul teoretic cu numeroase studii de calitate. R. Lesthaeghe, J. Surkyn, Z. Spéder, F. Camaras, S. Zaharov, L. Fialaova, T. Frejca, I.E. Kotowska, A. Baranowska, D. Kostova, C. Mureşan, etc. au analizat aprofundat profilurile de vârstă ale riscurilor de formare a uniunilor maritale și non-maritale în Rusia, România, Polonia, Ungaria, Bulgaria și Italia. Constatările de bază ale studiilor au relatat că există o variabilitate considerabilă în aceste populații privind nivelul, structura pe vârstă a riscurilor de intrare în aceste uniuni, având valori de la cele ridicate și precoce până la cele mult mai lente și târzii.

J. Seltzer vorbește despre rolurile economice, uniunile consensuale implică un angajament iniţial mai redus de a realiza responsabilitățile economice pe termen lung cerute de căsătorie. Când circumstanțele economice ale tinerilor adulți bărbați sunt precare, aceștia amână căsătoria; cei nesiguri din punct de vedere economic, inclusiv cei care sunt încă în sistemul de învăţământ, aleg mai degrabă parteneriatul în forma coabitării, în locul căsătoriei [6]. 
R. Lesthaeghe şi D.J. Van de Kaa, cei care au lansat ideea celei de a doua tranziţii demografice, fac referire la teoria lui Inglehart atunci când explică schimbarea petrecută la nivelul mentalității: când nevoile materiale sunt satisfăcute, are loc o trecere de la valori materialiste la valori post-materialiste. Teoria s-a confruntat cu numeroase critici, dintre care cele mai importante țin de elaborarea acesteia, pornind de la experiența unor țări vest- și nord-europene, cercetătorii fiind susceptibili la ideea răspândirii în sudul, centrul și estul continentului european. Apoi rămâne complexitatea legăturii dintre atitudini și comportament, fiind dificil de stabilit direcția cauzalităţii. Normele și atitudinile se pot schimba pentru a se adapta comportamentelor și nu neapărat invers. Schimbările vizibile în comportamentele legate de familie în țările est-europene, din anii '90 ai sec. $\mathrm{XX}$ au fost puse în special pe seama efectelor directe ale crizei socioeconomice declanşate de schimbarea regimului politic și de tranziția către economia de piaţă [9]

T. Sobotka studiind procesele transformaţionale din Europa, relatează despre influența mediului familial asupra comportamentului marital și reproductiv al tinerilor, legătura dintre coabitare, căsătorie și nivelul de studii [7].

Răspândirea comportamentelor asociate celei de a doua tranziţii demografice în România a fost documentată de C. Mureșan, care relatează că atractivitatea căsătoriei directe (neprecedate de coabitare) a scăzut începând din anii '90 ai sec. XX, concomitent cu creșterea numărului celor care încep un prim parteneriat sub forma unei coabitări, iar uniunile consensuale rămân mai mult în această formă decât în trecut (fără a fi transformate în căsătorie). Tot în lucrarea din 2008, la 25 de ani după lansarea conceptului celei de-a doua tranziții demografice, salarizează principalele rezultate asupra legăturii dintre aranjamente de viață neconvenționale (coabitare) și orientarea valorică [4].

In Republica Moldova studierea problemelor privind formarea și funcționarea familiei a fost abordată de O. Gagauz, care a cercetat problemele privind rolul familiei în reproducerea populației, viața de familie, influența factorilor sociodemografici asupra funcției de reproducere și comportamentului marital. Autoarea evidențiază că traiul în parteneriat ar însemna scăderea valorii căsătoriei în structura valorică a populației, pe când numeroase cercetări demonstrează că pentru cetățenii Republicii Moldova, printre valorile primordiale figurează familia, intimitatea, iubirea, sprijinul necondiționat, managementul de încredere și eficient în viaţa cotidiană [3].

Ulterior, tematica a fost reflectată în diferite studii consacrate modului și calității vieții, timpului liber, cercetărilor de gen (A. Timuş, T. Danii, A. Roşca, I. Bejan-Volc, etc.). Totodată, în Programul național strategic în domeniul securităţii demografice a Republicii Moldova (2011-2025) se menționează despre necesitatea cercetării diverselor subiecte axate pe familie și valorile ei. ${ }^{37}$

Date și metode. Potrivit datelor Biroului Național de Statistică, conform Recensământului Populației și Localităților din 2014, ponderea populației tânără (15-30 ani) care trăiește în uniune consensuală în Chișinău este de 4\%. Dintre totalul de persoane care au participat la Recensământ, $51,2 \%$ erau necăsătorite, $10,1 \%$ divorțate și $41,4 \%$ căsătorite. Tinerii cu vârstă de $20-24$ ani au cea mai mare pondere de trai în parteneriat- $6 \%$ din populația de această vârstă, urmaţi de cei din grupul de vârstă 25-29 cu 5,1\% și 2,6\% sunt tinerii maturi de 30-35 ani (Fig. 1.). Remarcabil este și faptul că aproape $2 \%$ din tineri trăiesc în parteneriat de la o vârstă fragedă (15-19 ani).

\footnotetext{
37 Hotărârea Guvernului Republicii Moldova cu privire la aprobarea Programului național strategic în domeniul securității demografice a Republicii Moldova (2011-2025): nr. 768 din 12.10.2011. Monitorul Oficial al Republicii Moldova, 2011, Nr: 182-186, art. Nr: 851.
} 


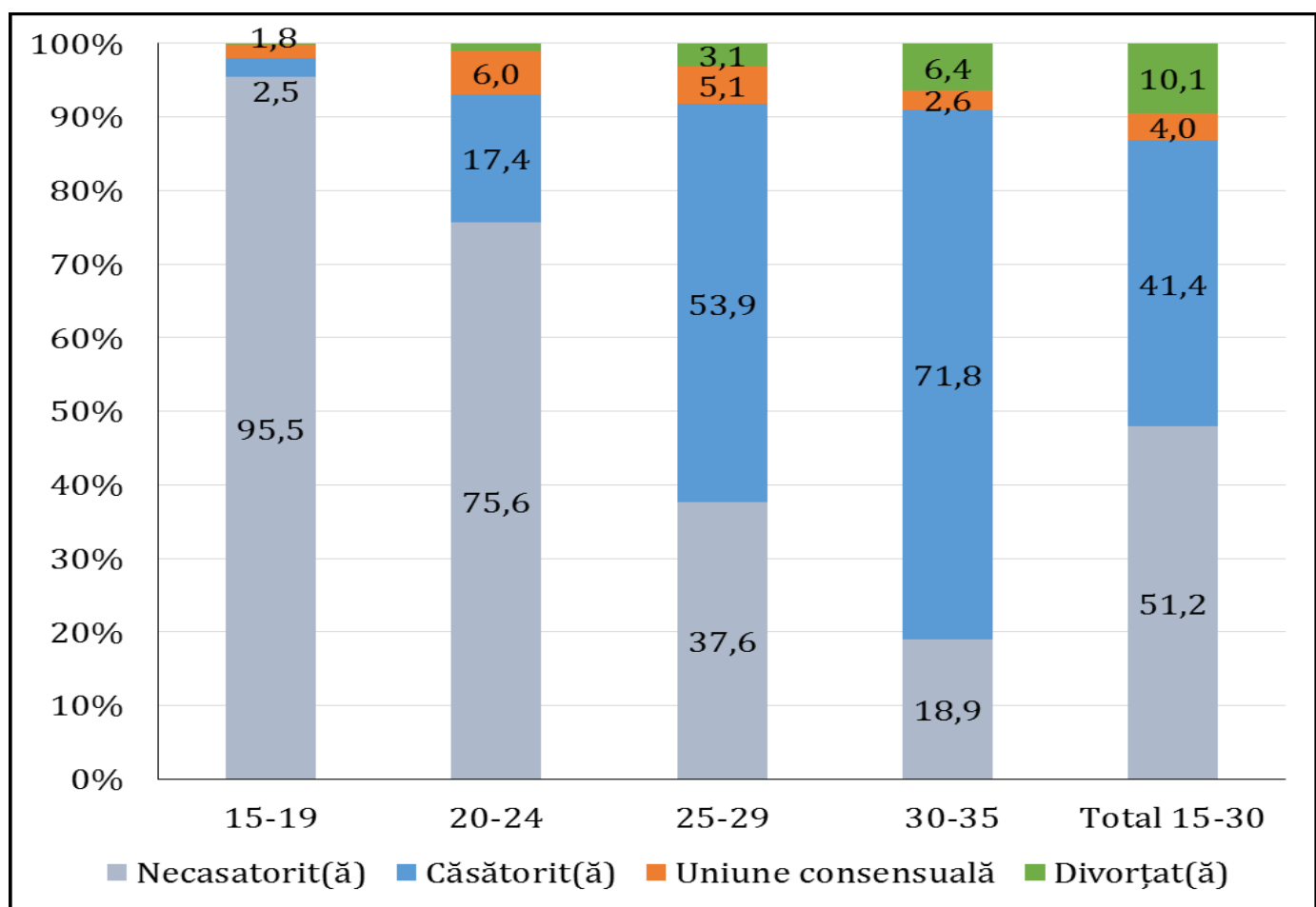

Sursa: Conform BNS ${ }^{39}$

Figura 1. Ponderea populației după starea civilă pe categorii de vârstă în municipiul Chișinău, conform RPL ${ }^{38}$ din 2014 (în \%)

Reieșind din aceste date, în articolul de față ne propunem să analizăm percepția tinerilor din municipiul Chișinău față de traiul în parteneriat sau atitudinea față de uniunile consensuale. În acest context au fost analizate datele studiului sociologic "Atitudinile tinerilor față de căsătorie" desfășurat la Centrul de Cercetări Demografice în anul 2019. Instrumentul de cercetare a fost ancheta sociologică pe bază de chestionar, care conținea 45 de întrebări dintre care au avut referință și la atitudinea față de traiul în parteneriat. Numărul mare de populaţie de vârstă tânăra nu a fost singurul considerent pentru care s-a desfășurat cercetarea doar în Chișinău, aici avem cel mai bine ilustrat statutul tinerilor, nivelul de școlarizare, situația ocupațională sau șomajul. În capitală, în 2018 rata nupțialității a constituit 6,7 la 1000 de locuitori și rata divorțialităţii de 3,3 la 1000 de locuitori comparativ cu media pe țară, care au fost 7,6 căsătorii și 3,4 divorțuri la 1000 de locuitori. Durata medie a căsniciei, desfăcută ulterior prin divorț, este de 11 ani (în comparație cu 19-20 ani în anii precedenți).

Cercetarea cantitativă a implicat 489 de respondenți necăsătoriţi din mun. Chișinău, dintre aceștia: 59,2\% -tinerii cu vârste cuprinse între 20 și 24 de ani; $21,9 \%$-fiind respondenți între 25 și 29 de ani; 18,9\% -30 și 35 de ani, dezagregați pe gen, au constituit 53\% de fete şi 47\% băieți. Divizarea respondenților în baza originii a cuprins 41,2 tineri originari din Chișinău și 58,2 migrați în Chișinău. Tinerii au fost repartizați și după experiența de trai în parteneriat, astfel constând 43,9\% cu experiență și 55,5\% fără experiență (Tabelul 2.).

\footnotetext{
${ }^{38}$ Recensământului Populației și Localităților din 2014.

${ }^{39}$ Biroului Naţional de Statistică.
} 
Tabelul 2. Repartizarea respondenților în \% pe indicatori și sub-indicatori

\begin{tabular}{|c|c|c|c|}
\hline Indicatori & Sub-indicatori & Total & Procente \\
\hline Sex & Feminin & $230 / 488$ & 53 \\
\hline & Masculin & $258 / 488$ & 47 \\
\hline Vârstă & $20-24$ ani & $289 / 488$ & 59,2 \\
\hline & $25-29$ ani & $107 / 488$ & 18,9 \\
\hline Nivel de studii & $30-35$ ani & $92 / 488$ & 44,6 \\
\hline & Gimnaziu, Liceu & $213 / 488$ & 23,8 \\
\hline & $\begin{array}{c}\text { Școală profesională sau } \\
\text { colegiu }\end{array}$ & $116 / 488$ & 32,6 \\
\hline Origine & $\begin{array}{c}\text { Studii universitare } \\
\text { (licență, masterat) }\end{array}$ & $159 / 488$ & 41,2 \\
\hline $\begin{array}{c}\text { Experiența de trai în } \\
\text { comun }\end{array}$ & Migrați în Chișinău & $201 / 488$ & 58,8 \\
\hline & Cu experiență & $287 / 488$ & 43,9 \\
\hline
\end{tabular}

Sursa: Datele studiului "Atitudinea tinerilor faţă de căsătorie” desfăşurat în 2019 la CCD

Rezultate. În Republica Moldova, potrivit prevederilor Codului Familiei, statul ocrotește din punct de vedere legal căsătoria și familia, adică apără interesele mamei și copilului și recunoaște căsătoria în fața ofițerului de stare civilă fără să facă vreo referire la alte forme de conviețuire. Așadar, se poate de subliniat că nu există o egalitate între căsătorie și uniunea consensuală. Totuşi comportamentul populației în această sfera s-a schimbat de-a lungul timpului, motivul fiind scăderea bruscă a nivelului de trai, migrația, creșterea inaccesibilităţii locuințelor, în special pentru familiile tinere [5].

Reieșind din această constatare și potrivit datelor studiului sociologic se observă că atitudinea tinerilor faţă de uniunile consensuale sunt mai mult pozitive decât negative, indiferent de genul acestora. Doar $12 \%$ de băieți și $10 \%$ de fete au declarat că sunt împotriva acestui mod de conviețuire (Fig. 2.).

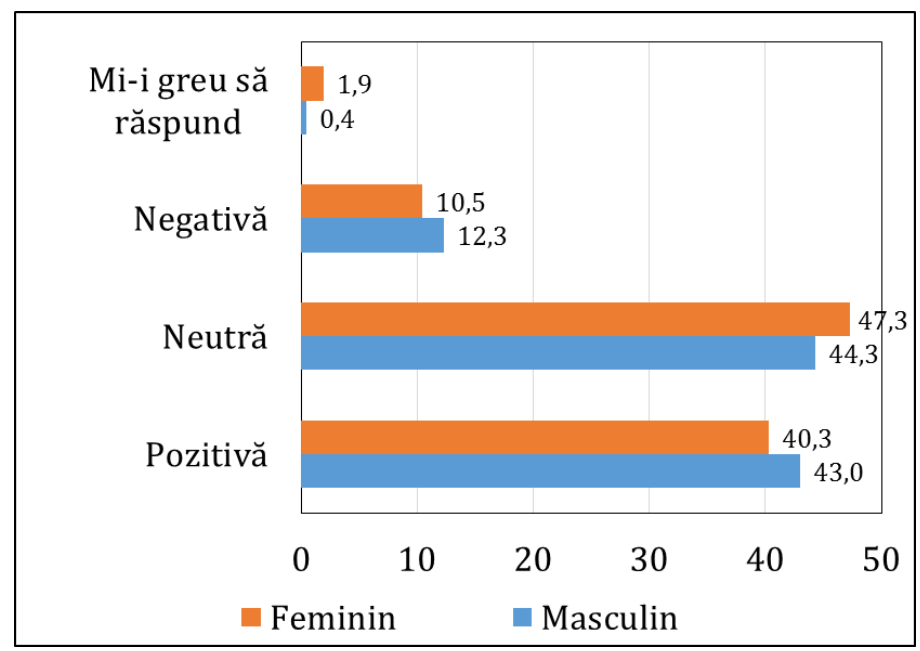

Figura 2. Atitudinea respondenților față de persoanele care locuiesc împreună și nu-și înregistrează căsătoria în dependență de sex

Sursa: Datele studiului "Atitudinea tinerilor față de căsătorie" desfășurat în 2019 la CCD 
Dacă analizăm în dependență de vârstă, atunci observăm că tinerii din grupul de vârstă de 25-29 de ani au declarat o atitudine permisivă față de traiul în comun fără înregistrarea căsătoriei (51,9 \% au atitudine pozitivă). O atitudine neutră au declarat tinerii din grupul de vârstă 20-24 ani47,9\% și 51,1\% din grupul de vârstă 30-35 ani (Fig. 3.). Aceste rezultate ne permit să emitem ipoteza conform căreia indecișii, în cea mai mare parte, vor evolua spre atitudinea pozitivă față de acest tip de conviețuire. În contextul acestor date nu este întâmplător faptul că cca 41,4\% din respondenți au o atitudine pozitivă despre tinerii care practică acest tip de conviețuire și nu-și înregistrează căsătoria. Aceasta se poate explica prin faptul că schimbarea condițiilor de viață, în mod deosebit prelungirea duratei de studii, prioritatea profesionalizării, cerințele mari de calificare necesare asigurării unui loc de muncă, îi determină pe tineri să aibă o atitudine permisivă față de traiul în uniune consensuală.

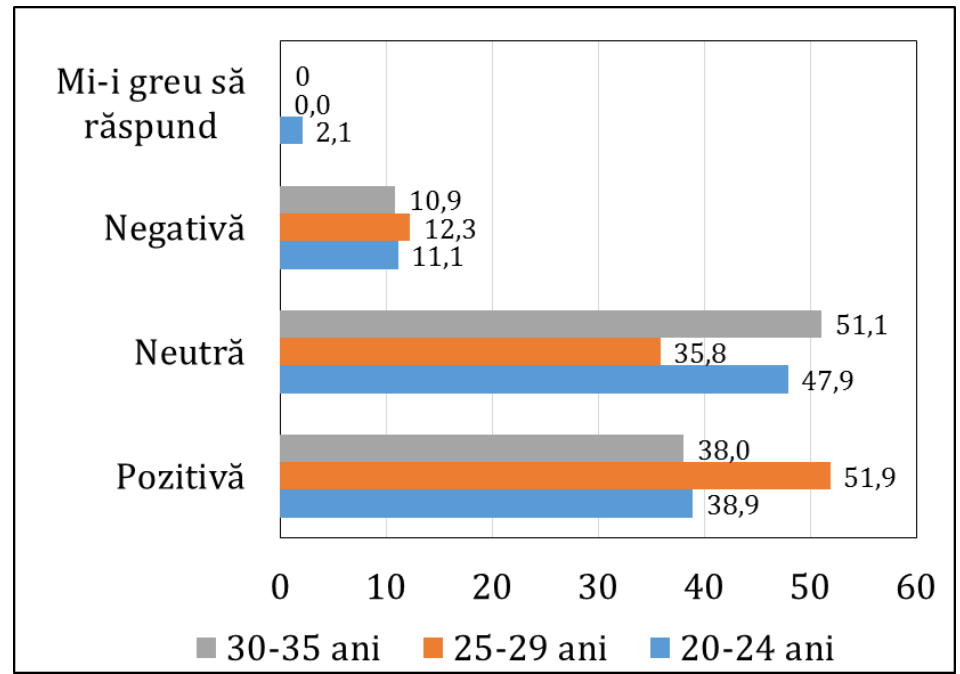

Figura 3. Atitudinea respondenților față de persoanele care locuiesc împreună și nu-și înregistrează căsătoria în dependență de vârstă

Sursa: Datele studiului "Atitudinea tinerilor față de căsătorie" desfăşurat în 2019 la CCD

Specialiștii din domeniu mai explică acest proces prin școlarizarea prelungită a tinerilor, însă datele studiului au demonstrat că atitudinea pozitivă faţă de coabitarea înainte de căsătorie este răspândită la tineri sub toate nivelurile de studii, iar tinerii cu studii superioare sunt în proporție mai mare atât la atitudinea pozitivă $(44,7 \%)$, cât și la cea negativă $(13,2 \%)$, în comparație cu ceilalți, ceea ce dă dovadă că sunt mai hotărâți în decizii (Fig. 4.). Tinerii care au doar gimnaziul sau liceu sunt indiferenți faţă de acest tip de conviețuire, declarând o atitudine neutră, la fel și cei cu școală profesională sau colegiu. Generația tânără până acum câțiva ani își planifică căsătoria imediat după absolvirea studiilor universitare. În prezent lucrurile s-au modificat, asistăm la o reducere a căsătoriilor și o creștere lentă a numărului de divorțuri. Discordanța în timp dintre atingerea de către tineri a maturității fiziologice, precum și liberalizarea moravurilor referitor la practicarea relațiilor sexuale înainte de căsătorie, duce la răspândirea conviețuirii înainte de căsătorie [2]. 


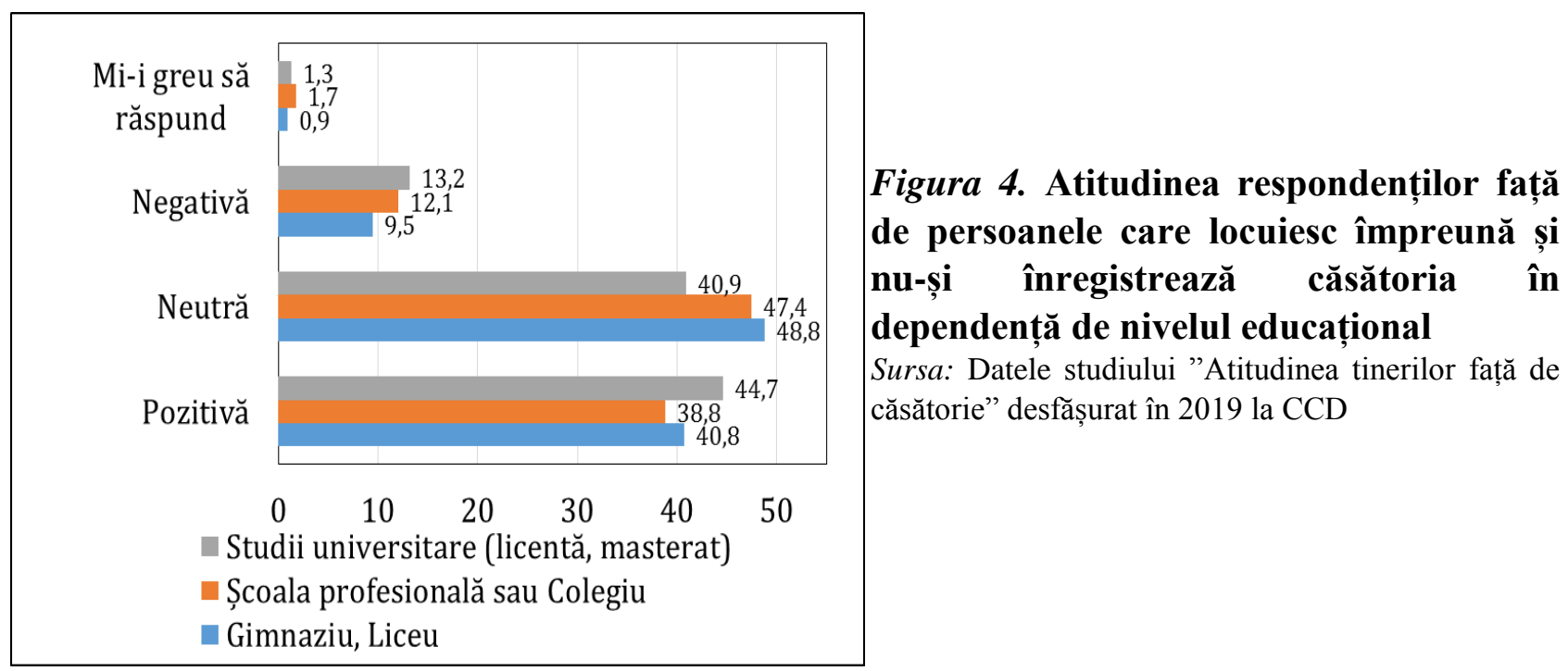

Chiar dacă traiul în parteneriat este acceptat de un segment important al celor chestionaţi, căsătoria oficială și instituția familiei rămân în continuare valori importante în percepția tinerilor. Astfel, 85,12\% din tinerii chestionați au preferat căsătoria oficială. Această viziune este afirmată în proporție mai mare de toți respondenții și nu depinde de gen sau vârstă. Totuși pentru bărbați există o perioadă a vieții când traiul în uniune consensuală este mai relevant. Conform studiului, băieții din grupul de vârstă de 25-29 de ani în proporție de $24,4 \%$ au declarat că preferă conviețuirea în parteneriat (Fig. 5.). Având în vedere că la această vârstă mulți din ei finalizează studiile și se încadrează în viaţa profesională, nu dispun de timp mai mult pentru viața personală, din acest considerent amână oficializarea relațiilor. Această atitudine o observăm și în rândul fetelor la acest grup de vârstă, $17,2 \%$ preferă viața în comun fără legalizarea relatiiilor.

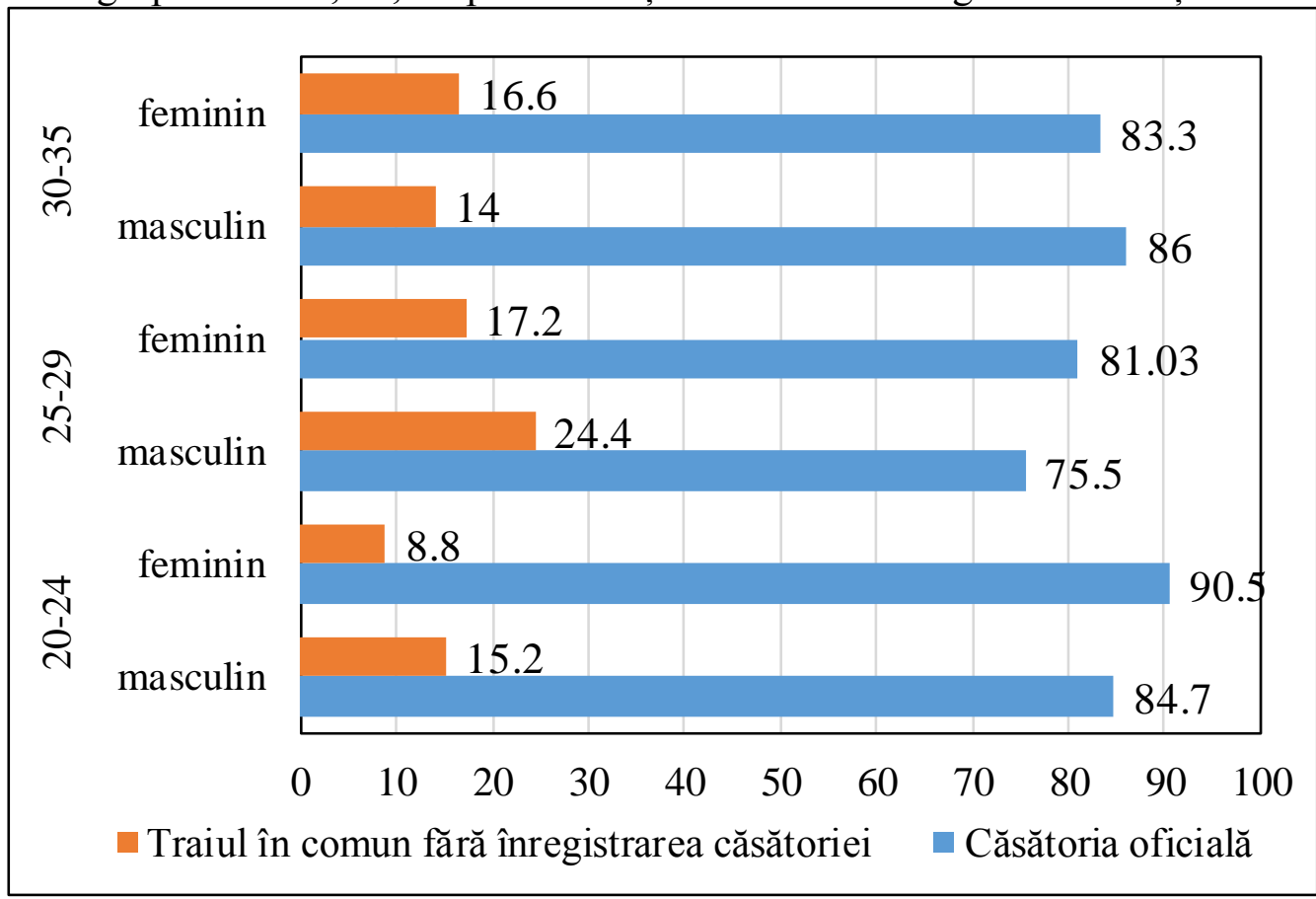

Figura 5. Preferințele respondenților după tipul de conviețuire preferat, pe sexe și vârstă (în \%)

Sursa: Datele studiului "Atitudinea tinerilor față de căsătorie" desfășurat în 2019 la CCD 
Conform studiului, fetele în număr mai mare trăiesc în uniune consensuală comparativ cu băieții, totuși în proporție mai mare în grupul de vârstă de 25-29 ani și 30-35 ani $(66,6 \%$ au declarat că au experiență de trai în comun). Tinerii din grupul de vârstă 20-24 ani au mai puțină experiență de trai în comun (fetele-35,45\% și băieții-28,2\%) (Fig. 6.). Influența vârstei în ceea ce privește statutul din punctul de vedere al relațiilor este relativ intuitivă. După cum putem observa, tinerii cu vârste cuprinse între $20-24$ ani mai puțin își asumă responsabilitatea să trăiască în parteneriat. Pe măsură ce avansează în vârstă, crește prevalența celor care coabitează.

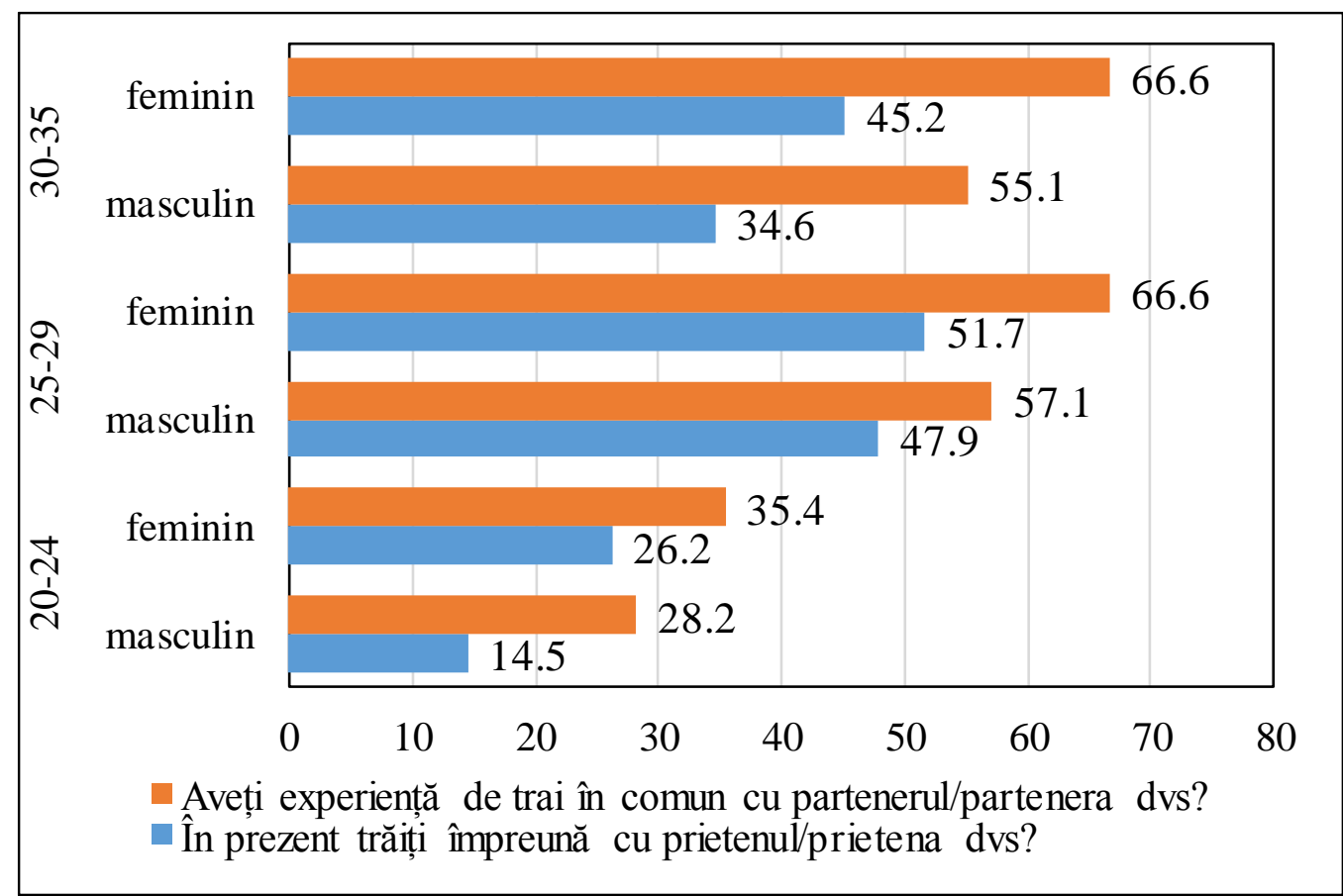

Figura 6. Ponderea respondenților după experiența de viață în parteneriat (în \% pe sexe și vârstă)

Sursa: Datele studiului "Atitudinea tinerilor față de căsătorie" desfășurat în 2019 la CCD

Această constatare nu este atât de surprinzătoare, deoarece principalele condiții pentru care tinerii ar fi gata să formeze o familie sunt finalizarea studiilor $(46,6 \%)$ și asigurarea financiară $(28,8 \%)$, totodată și deținerea unui loc de muncă care ar asigura bunăstarea financiară $(21 \%)($ Fig. 7.). Este evident că tinerii în vârstă de 20-24 ani încă nu au reușit să-şi asigure independența materială și statutul social necesar, din aceste considerente, în proporție de $65,4 \%$ au optat pentru finalizarea studiilor, iar tinerii din grupul de vârstă 25-29 ani au optat pentru asigurarea financiară $(48,6 \%)$ (Fig. 8.). 


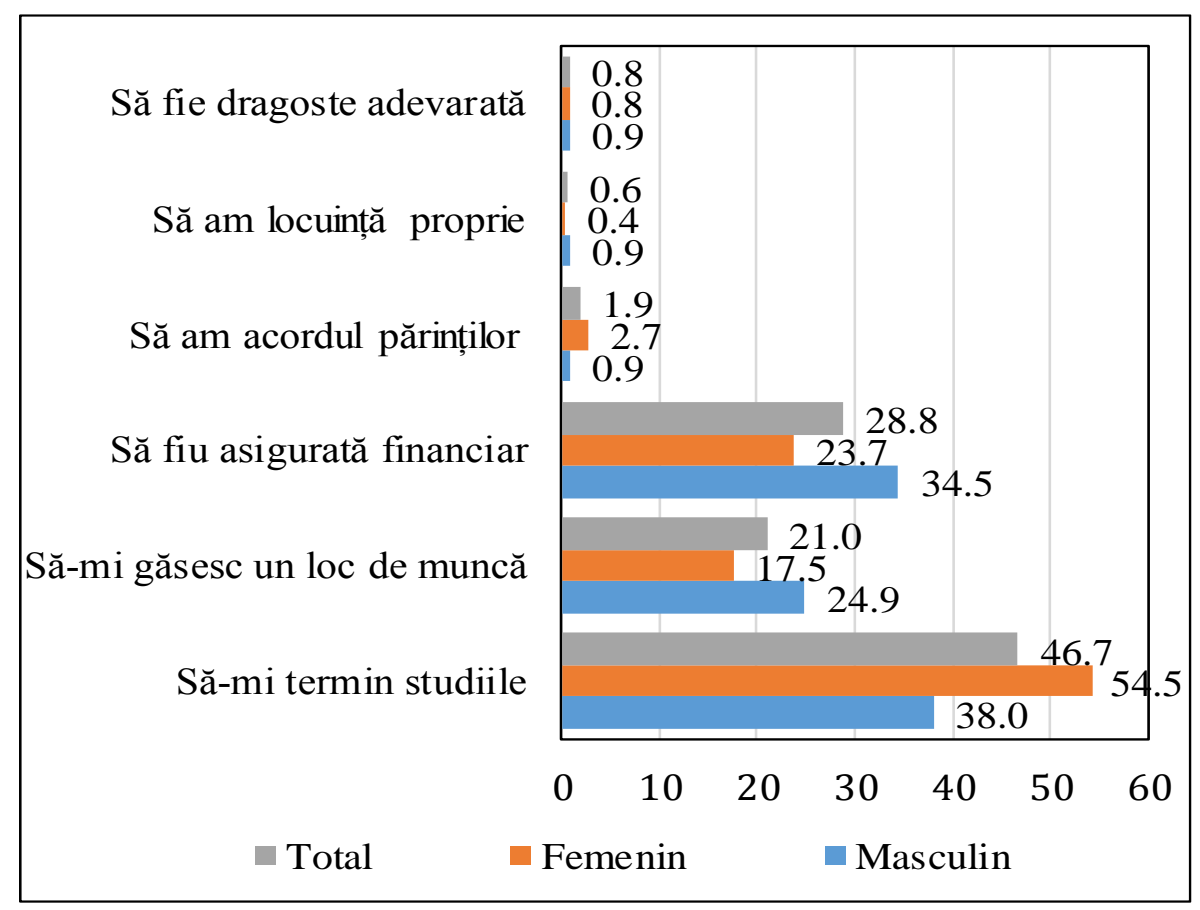

Figura 7. Repartizarea viziunii tinerilor față de principalele condiții pentru întemeierea unei familii, pe sexe

Sursa: Datele studiului "Atitudinea tinerilor față de căsătorie" desfăşurat în 2019 la CCD

Remarcabil este faptul că tinerii din grupul de vârstă de 30-35 ani care au experiență de trai în parteneriat mai mare, în proporție de 39,1, văd opțiunea unui loc de muncă la fel de importantă ca și asigurarea financiară. Chiar dacă această categorie de tineri sunt la o vârstă când dorința dea forma o familie este mai mare și experiența profesională mai bogată, ei totuși nu au reușit să atingă satisfacția financiară dorită. La fel se conturează problema locurilor de muncă și șomajul de proporții, care are efect negativ asupra deciziei de a se căsători.

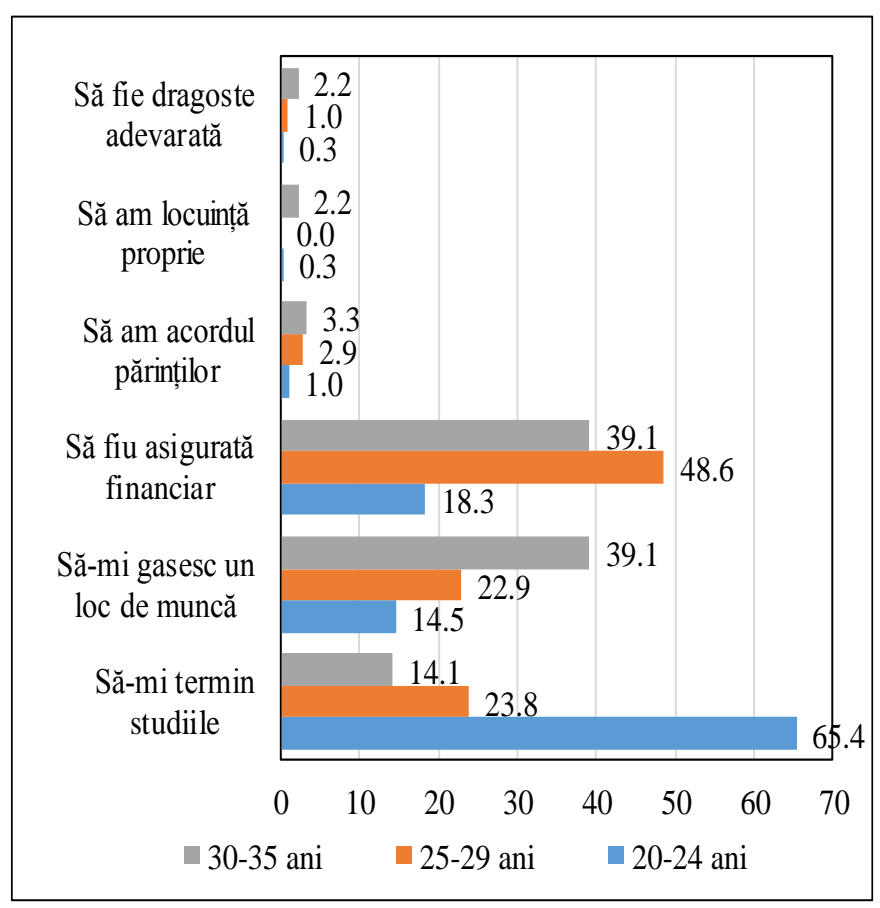

\section{Figura 8. Repartizarea viziunii tinerilor față de principalele condiții pentru întemeierea unei familii, pe grupuri de vârstă}

Sursa: Datele studiului "Atitudinea tinerilor față de căsătorie" desfăşurat în 2019 la CCD 
Analizând aceste rezultate, ne permitem să confirmăm unele concluzii referitoare la particularitățile traiului în parteneriat în societatea noastră în comparație cu societățile occidentale. În Republica Moldova, traiul în uniune consensuală nu este o decizie definitivă a comportamentului tinerilor, ci mai degrabă o formă ce precedă căsătoria. Cei mai mulți dintre intervievați acceptă această formă de conviețuire, considerând că ea este un ,test inainte de căsătorie" (70\% sunt de părere că este o necesitate conviețuirea înaintea căsătoriei (Fig. 9.)) și oferă posibilitatea de a se cunoaște mai bine cu persoana cu care doresc să-și construiască viitorul. După cum demonstrează datele cercetării, marea majoritate menționează totuşi că copiii trebuie să se nască după oficializarea căsătoriei, pentru a avea protecție juridică atât copiii, cât și soții. Acest fapt duce doar la satisfacerea nevoilor personale și ignorarea apariției copiilor.

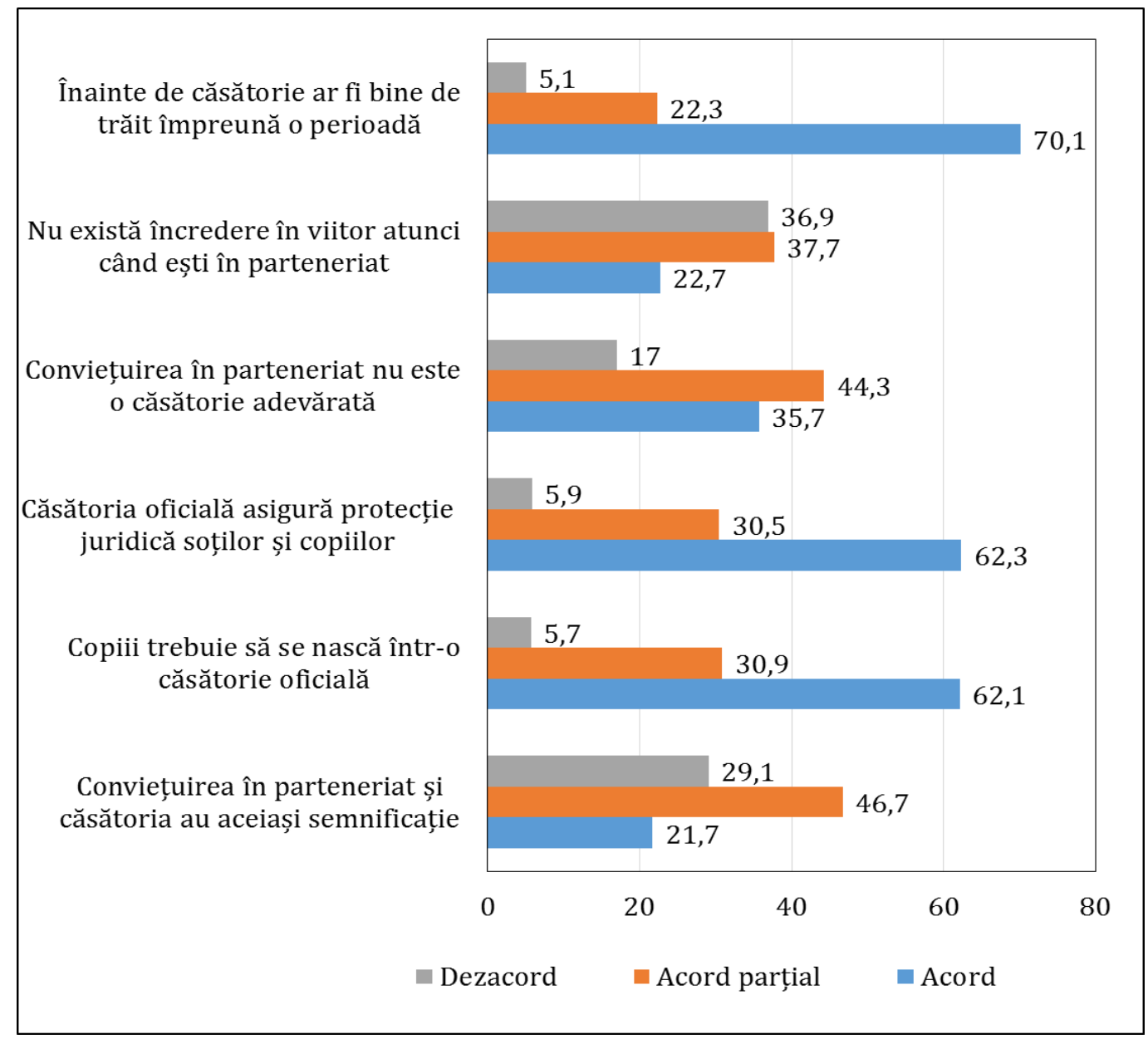

Figura 9. Opinia tinerilor vizavi de unele afirmații

Sursa: Datele studiului "Atitudinea tinerilor față de căsătorie" desfășurat în 2019 la CCD

Tinerii sunt sceptici în ceea ce privește încrederea în viitor fără oficializarea căsătoriei. Traiul în parteneriat nu răspunde nevoii de securitate, pentru că angajamentul este pe termen scurt. Partenerii cred că vor rămâne împreună atât timp cât nevoile lor sunt satisfăcute. Insecuritatea emoțională și materială este bine compensată în căsătorie, din acest motiv majoritatea tinerilor sunt parțial de acord că căsătoria și traiul în comun au aceeași semnificație.

\section{Concluzii}

Analizând datele studiului de faţă, putem concluziona că modelele de conviețuire și formele de coabitare acceptate în țările occidentale sunt relativ percepute în țara noastră. Tinerii îmbină 
elemente ale tradiționalismului cu modernul, având tendințe postmoderne datorate unui efect de a dori imitarea celorlalte societăți europene. Atitudinea lor față de traiul în uniuni consensuale este mai mult o consecință a condițiilor de viață a societății actuale. Răspândirea standardelor noi în comportamentul matrimonial și tendințele de dezvoltare a societății actuale au influențat asupra unor factori care au favorizat popularitatea acestui fenomen:

1. Cele mai semnificative motive care îi împiedică pe tineri să se căsătorească este incertitudinea în care se află, perioada de probă pentru tineri este prioritară pentru a stabili cu certitudine compatibilitatea caracterelor și a intereselor.

2. Situația complicată în care se află tinerii, lipsa locurilor de muncă și a resurselor financiare contribuie la alegerea formelor de conviețuire cu mai puține responsabilităţi. Totodată, pentru o bună parte din tineri studiile și cariera au prioritate mai mare în viață de cât familia.

3. Indiferent de faptul că căsătoria este preferată de tineri și recunosc că în așa mod sunt protejaţi legal, ei au o atitudine pozitivă față de traiul în parteneriat. Experiența de trai în uniune consensuală a tinerilor tot mai mult favorizează această formă de conviețuire.

\section{Bibliografie}

1. Antigona I. Istoria căsătoriei și a divorțului. Doctrină și Jurisprudență, București, 2016, nr. $1-2$, p. 78.

2. Chistruga-Sînchevici I. Comportamentul premarital al tinerilor: Evoluții si factori determinanți. Revista de Filozofie, Sociologie și Știinţe Politice, 2009, nr. 1 (149), p. 111.

3. Gagauz O. Familia contemporană între tradițional și modern. Chișinău, 2011, p. 123.

4. Mureşan C. Cohabitation, an alternative for marriage in contemporary Romania: A life table description. Demográfia (English edition), 2008, vol. 51, nr. 5, p. 36-65. https://pdfs.semanticscholar.org/7709/b4a50240e0ac8036d5659efefabf8e3e8eaf.pdf.

5. Pahomi I. Transformarea familiei în Republica Moldova: convergența și divergența în contextul tendinţelor europene. Analele Institutului Național de Cercetări Economice. Ediția a V-a. Chișinău, 2015, nr. 1, p.104.

6. Seltzer J. A. Families Formed outside of Marriage. Journal of Marriage and Family, 2000, nr. 62 (4), p. 1247-1268.

7. Sobotka T. Overview Chapter 6: The diverse faces of the Second Demographic Transition in Europe. Demographic Research, 2008, nr. 19, p. 171-224. https://www.demographicresearch.org/volumes/vol19/8/19-8.pdf.

8. Studiu comparativ privind reglementările legale din statele Uniunii Europene care au ca obiect recunoașterea și protecția cuplurilor de același sex. Reglementarea parteneriatului civil și a căsătoriilor între persoane de același sex din Europa, p. 25.

9. Van de Kaa Dirk J. The Idea of a Second Demographic Transition in Industrialized Countries. The Sixth Welfare Policy Seminar of the National Institute of Population and Social Security, Tokyo, Japan, 292002. https://pdfs.semanticscholar.org/17c8/c2c3b43d447474107554926eb289d269c939.pdf. 